Bull. Chem. Soc. Ethiop. 2017, 31(3), 445-456.

ISSN 1011-3924

(C) 2017 Chemical Society of Ethiopia and The Authors

Printed in Ethiopia

DOI: http://dx.doi.org/10.4314/bcse.v31i3.8

\title{
SYNTHESIS OF SCHIFF BASES DERIVED FROM 2-HYDROXY-1-NAPHTH- ALDEHYDE AND THEIR TIN(II) COMPLEXES FOR ANTIMICRIBIAL AND ANTIOXIDANT ACTIVITIES
}

\author{
Neelofar ${ }^{1}$, Nauman $\mathrm{Ali}^{1 *}$, Adnan Khan ${ }^{1}$, Salma Amir ${ }^{1}$, Noureen Amir Khan ${ }^{2}$ and Muhammad \\ Bilal $^{3}$ \\ ${ }^{1}$ Institute of Chemical Sciences, University of Peshawar, Pakistan \\ ${ }^{2}$ National Centre of Excellence in Physical Chemistry, University of Peshawar, Pakistan \\ ${ }^{3}$ Hayatabad Medical Complex, Peshawar, Pakistan
}

(Received July 3, 2017; Revised January 8, 2018; Accepted January 13, 2018)

\begin{abstract}
The current studies were designed to prepare tin(II) complexes of various Schiff base derivatives of 2-hydroxy-1-naphthaldehyde $(\mathrm{HN})$ with L-histidine and sulfamethazine have been prepared and characterized by different physiochemical studies such as elemental analysis, atomic absorption, UV-Vis spectra, FTIR spectra, ${ }^{1} \mathrm{H}-\mathrm{NMR},{ }^{13} \mathrm{C}-\mathrm{NMR}$ and conductance studies. Antimicrobial and antioxidant activities were also calculated. Antibacterial activity was evaluated by the agar-well diffusion method. Two Gram-negative (Klebsiella pneumoniae and Escherichia coli) and three Gram-positive (Staphylococcus aureus, Staphylococcus epidermidis and Bacillus subtilis) bacterial strains were used. Antifungal activity was resolute against three fungal strains (Aspergillus niger, Aspergillus flavus and Alternaria solani) by using the agar tube dilution method. The antioxidant activity of ligands and their complexes was measured on the basis of the radical scavenging effect of 1,1-diphenyl-2-picryl-hydrazyl (DPPH)-free radical activity. Ligand HNSM exhibited excellent activities as antibacterial activity $(22 \mathrm{~mm})$, antifungal activity $(55 \%)$ and antioxidant activity (119 ppm).
\end{abstract}

KEY WORDS: Schiff base, 2-Hydroxy-1-naphthaldehyde, L-Histidine and sulfamethazine, Tin(II) complexes, Antimicrobial activities, Antioxidant activities

\section{INTRODUCTION}

Schiff bases are formed by reacting aldehydes or ketones with amines to form imine or azomethine group. These Schiff bases are extensively utilized as drugs which are biological active compounds due this reason it is widely used for industries [1, 2]. Schiff bases are important due to carbon nitrogen double bond $(\mathrm{C}=\mathrm{N})$ which can coordinate with metal [3]. These important compounds have been reported to possess diverse biological activities such as antifungal, analgesic, anti-inflammatory, antibacterial, antioxidant, antitumor, cardiovascular, antitubercular [4-7] and as local anesthetic [8]. Apart from these synthetic imine groups are synthesized in labs various natural products compounds. The imine group present in such compounds has been shown to be critical in their biological activities. Schiff base ligands are able to coordinate in various oxidation states with many different metals [9]. Amino acids have importance in Schiff base complexes formation in which these can act as ligands due to their physiological and pharmacological activities. Moreover, these metal chelates appear to be involved in many of biological processes, such as transamination, racemization and carboxylation [10]. In particular histidine is a very important bioactive amino acid. The histidine binding to transition metal ions in biological systems has a major physicochemical role in several proteins as well as involved in the X-ray structural determination studies of metalloproteins like carbonic anhydrase, carboxypeptidase and plastocyanin. Additionally, histidine acting as the major zinc binding moiety in serum thus plays a major role in the zinc metabolism [11]. Hence, this histidine moiety is probably the most important metal-binding site in a large number of enzyme active centres in biological system. Furthermore, histidine seems to

*Corresponding author. E-mail: nali75pk@uop.edu.pk

This work is licensed under the Creative Commons Attribution 4.0 International License 
be involved in copper transport in blood [12]. Sulfonamides are an important class of antimicrobial agents owing to their low toxicity, low cost and excellent activity against bacterial diseases. They have the ability to prevent or slow down bacterial multiplication in wounds or infected systems without appreciable toxicity to the body tissues, thus sulfonamides are bacteriostatic rather than bactericidal [13]. Several sulfonamides Schiff bases were found to exhibit a wide spectrum of biological activities [14]. The chemistry of sulfonamides has been recently known as synthons in the preparation of various valuable biologically active compounds used as antibacterial, antitumor [15] and diuretic [16]. N-Substituted sulfonamides are recognized as anti-thyroid, anti-carbonic anhydrase, hypoglycaemic, and protease inhibitors [17].

We have reported herein the synthesis of Schiff bases derived from 2-hydroxy-1naphthaldehyde $(\mathrm{HN})$ with L-histidine and sulfamethazine and their complexes with inorganic tin(II) chloride. The study of these synthesized Schiff base ligands and their metal complexes have been correlated to their biological and antioxidant activities with their structural aspects.

\section{EXPERIMENTAL}

\section{Chemicals and reagents}

Solvents used in this study were of analytical grade. Tin(II) chloride, 2-hydroxy-1naphthaldehyde, L-histidine and sulfamethazine were of analytical grade and purchased from Sigma-Aldrich (Steinheim, Germany).

Instruments/equipments

${ }^{1} \mathrm{H}-\mathrm{NMR}$ and ${ }^{13} \mathrm{C}-\mathrm{NMR}$ were recorded at $400 \mathrm{MHz}$ for ${ }^{1} \mathrm{H}$ and at $100 \mathrm{MHz}$ for ${ }^{13} \mathrm{C}$ using TMS as internal standard with Bruker DPX-400 instrument in deuterated solutions. IR spectra were determined using a Jasco A-302 spectrophotometer. UV-Visible spectra were recorded using SP-3000 PLUS (Optima, Japan) spectrophotometers.

\section{Bacterial and fungal strains}

Two Gram-negative (Klebsiella pneumoniae and Escherichia coli) and three Gram-positive (Staphylococcus aureus, Staphylococcus epidermidis and Bacillus subtilis) for antibacterial activity and three fungal strains (Aspergillus niger, Aspergillus flavus and Alternaria solani) for antifungal activity were used for evaluation of microbial activities.

\section{Preparation of ligands}

Ligands were prepared according to the reported method in literature [18]. Equimolar ethanolic solution of 2-hydroxy-1-naphthaldehyde $(0.01 \mathrm{~mol}, 1.7218 \mathrm{~g})$ and L-histidine $(0.01 \mathrm{~mol}, 1.553$ g) and sulfamethazine $(0.01 \mathrm{~mol}, 2.901 \mathrm{~g})$ separately were refluxed with constant stirring for 40 min (Scheme 1). The precipitates formed were separated by sintered glass crucible and were dried in vacuum oven. Ligands were re-precipitated with ethanol. Physical properties of the synthesized ligands are given in Table 1.

\section{Preparation of complexes}

The complexes were prepared by the method in literature [19]. Equimolar ethanolic solution of ligands ( $\mathrm{HNLH}$ and HNSM) $(0.0025 \mathrm{~mol})$ and $\mathrm{SnCl}_{2} \cdot 2 \mathrm{H}_{2} \mathrm{O}(0.0025 \mathrm{~mol})$ were refluxed with constant stirring for $2 \mathrm{~h}$ (Scheme 2). The precipitate formed was separated by filtering through 
sintered glass crucible and were washed with ethanol for the removal of unreacted material. Afterwards samples were dried in vacuum oven. Physical properties of the synthesized complexes are given in Table 1.

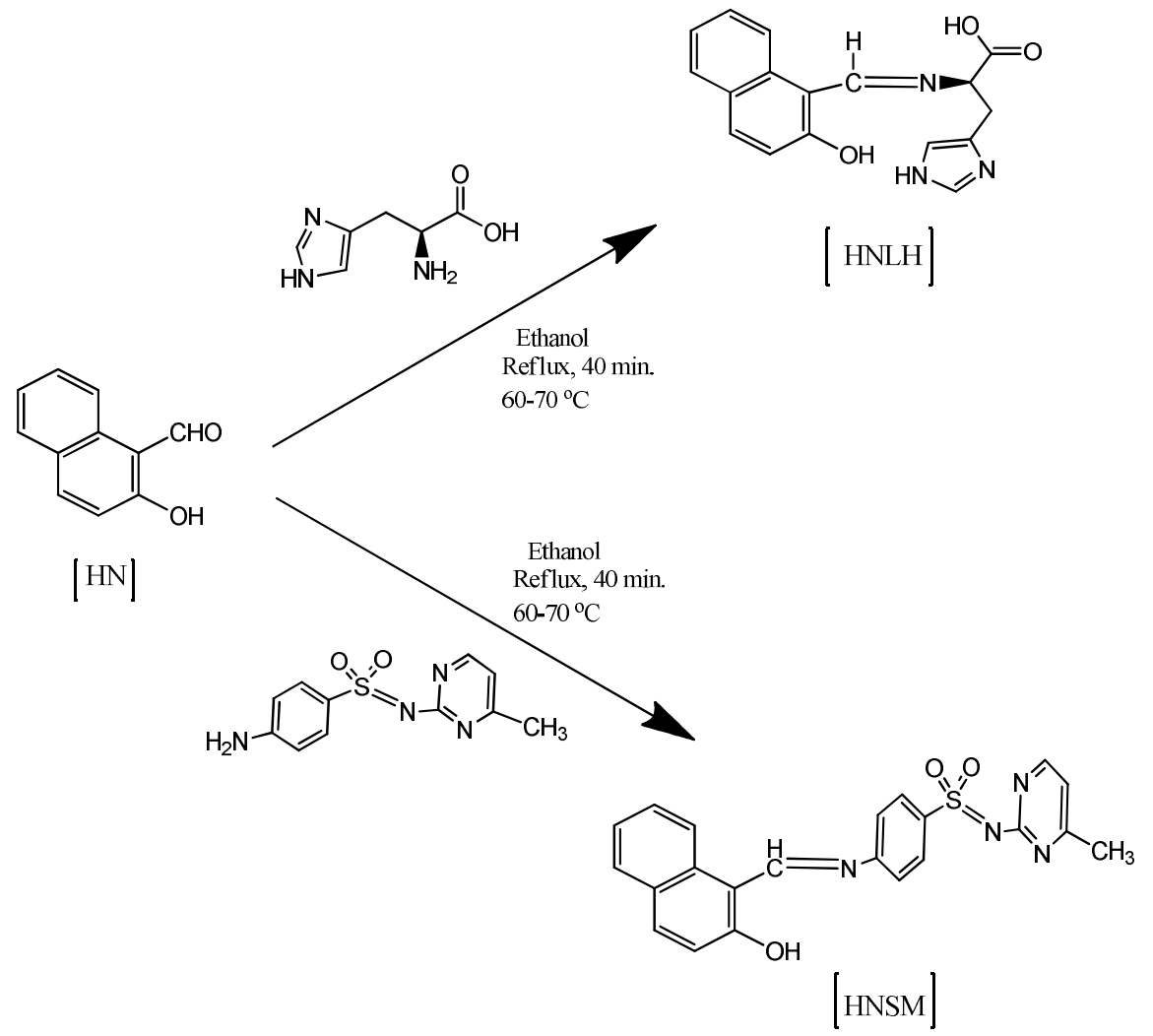

Scheme 1. Synthesis of ligands (HNLH and HNSM).

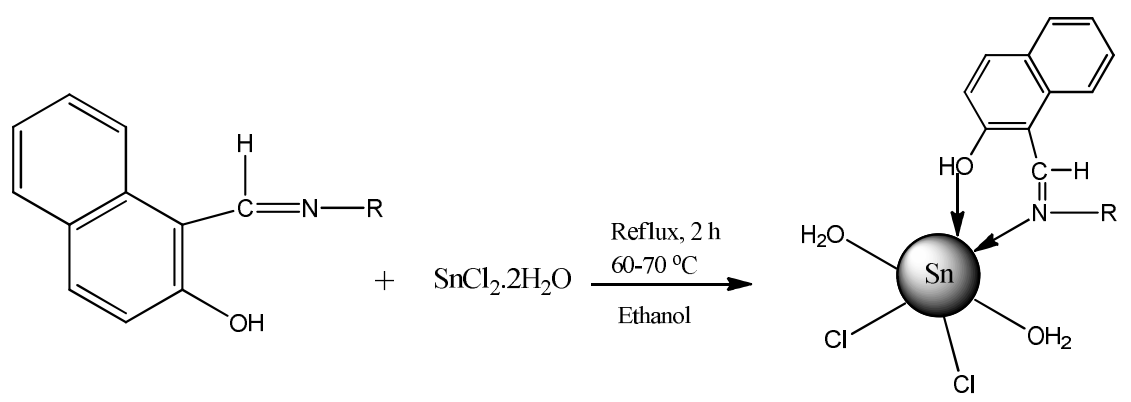

Ligand

Salt

Complex

Scheme 2. Synthesis of complex.

Bull. Chem. Soc. Ethiop. 2017, 31(3) 
Table 1. Physical properties of the ligands and their corresponding complexes.

\begin{tabular}{|l|c|c|}
\hline Compounds & Physical state & Colour \\
\hline HNLH & Powder & Mud colour \\
\hline$\left[\mathrm{Sn}(\mathrm{HNLH}) \mathrm{Cl}_{2}\left(\mathrm{H}_{2} \mathrm{O}\right)\right]$ & Powder & Pale yellow \\
\hline $\mathrm{HNSM}$ & Powder & Light brown \\
\hline$\left[\mathrm{Sn}(\mathrm{HNSM}) \mathrm{Cl}_{2}\left(\mathrm{H}_{2} \mathrm{O}\right)_{2}\right]$ & Powder & Maroon \\
\hline
\end{tabular}

Antibacterial assay (in vitro)

The synthesized Schiff bases (HNLH and HNSM) and their tin(II) complexes $\left(\left[\mathrm{Sn}(\mathrm{HNLH}) \mathrm{Cl}_{2}\left(\mathrm{H}_{2} \mathrm{O}\right)\right]\right.$ and $\left.\left[\mathrm{Sn}(\mathrm{HNSM}) \mathrm{Cl}_{2}\left(\mathrm{H}_{2} \mathrm{O}\right)_{2}\right]\right)$ were screened in vitro for their antibacterial activity against two Gram-negative (Klebsiella pneumoniae and Escherichia coli) and three Gram-positive (Staphylococcus aureus, Staphylococcus epidermidis and Bacillus subtilis) bacterial strains by the agar-well diffusion method. The wells $(6 \mathrm{~mm}$ in diameter) were dug in the media with the help of a sterile metallic borer. Bacterial inocula (2-8 h old) containing approximately 104-106 colony-forming units $(\mathrm{CFU} / \mathrm{mL})$ were spread on the surface of the nutrient agar with the help of a sterile cotton swab. The recommended concentration of the test sample $(1 \mathrm{mg} / \mathrm{mL})$ in DMSO was introduced in the respective wells. Other wells supplemented with DMSO and reference antibacterial drug, imipenum served as negative and positive controls, respectively. The plates were incubated at $37^{\circ} \mathrm{C}$ for $24 \mathrm{~h}$. Activity was determined by measuring the diameter of zones showing complete inhibition $(\mathrm{mm})$ [20-21]. In order to evaluate the interfering effect of DMSO on the biological screening, alternate studies on DMSO solution showed no activity against any bacterial strains.

\section{Antifungal assay}

Antifungal activity against three fungal strains (Aspergillus niger, Aspergillus flavus and Alternaria solani) was determined by using the agar tube dilution method. Screw caped test tubes containing sabouraud dextrose agar (SDA) medium $(4 \mathrm{~mL})$ were autoclaved at $121^{\circ} \mathrm{C}$ for $15 \mathrm{~min}$. The tubes were allowed to cool at $50{ }^{\circ} \mathrm{C}$ and non-solidified SDA was loaded with 66.6 $\mu \mathrm{L}$ of compound from the stock solution ( $12 \mathrm{mg} / \mathrm{mL}$ in DMSO) to make a $200 \mu \mathrm{g} / \mathrm{mL}$ final concentration. The tubes were then solidifying a slanting position at room temperature. Each tube was inoculated with a $4 \mathrm{~mm}$ diameter piece of inoculum from seven days old fungal culture. The media was supplemented with DMSO and Turbinafine $(200 \mu \mathrm{g} / \mathrm{mL})$ were used as a negative and a positive control, respectively [22].

Antioxidant activity (DPPH free radical scavenging activity)

The antioxidant activity of ligands and their corresponding tin(II) complexes and the standard were assessed on the basis of the radical scavenging effect of 1-diphenyl-2-picryl-hydrazyl (DPPH)-free radical activity by modified method. A freshly prepared DPPH solution exhibited a deep purple colour with a maximum absorption at $517 \mathrm{~nm}$. This purple colour disappears when an antioxidant is present in the medium. Therefore, antioxidant molecules can quench DPPH free radicals and convert them to a colourless product, resulting in a decrease in absorbance at $517 \mathrm{~nm}$.

The diluted working solutions of the test samples were prepared in methanol. Ascorbic acid was used as standard in $1-100 \mu \mathrm{g} / \mathrm{mL}$ solution. $0.002 \%$ of DPPH was prepared in methanol and $2 \mathrm{~mL}$ of this solution was mixed with $1 \mathrm{~mL}$ of sample solution and standard solution separately. These solution mixtures were kept in dark for 30 min and optical density was measured at 517 $\mathrm{nm}$ using Cecil-Elect Spectrophotometer. Methanol $(1 \mathrm{~mL})$ with DPPH solution $(0.002 \%, 1 \mathrm{~mL})$ 
was used as blank. The free radical scavenging activities are expressed as the ratio percentage of the sample absorbance decrease and the absorbance of tested compound at $517 \mathrm{~nm}$. The optical density was recorded and $\%$ inhibition was calculated using the formula [23]:

Percent $(\%)$ inhibition of DPPH activity $=(\mathrm{A}-\mathrm{B}) / \mathrm{A} \times 100$

where $\mathrm{A}=$ optical density of the blank and $\mathrm{B}=$ optical density of the sample. DPPH free radical scavenging activity \% was proportional to the concentration of the tested compounds. Concentration of the sample at which the inhibition percentage reaches $50 \%$ is its $\mathrm{IC}_{50}$ value. $\mathrm{IC}_{50}$ value is negatively related to the antioxidant activity, as it expresses the amount of antioxidant needed to decrease its radical concentration by $50 \%$.

\section{RESULTS AND DISCUSSION}

\section{Elemental analysis and atomic absorption studies}

The close agreement in the calculated and found values of the elemental analysis have shown the formation of ligands (HNLH and HNSM) and complexes ([Sn(HNLH)Cl $\left.\mathrm{Cl}_{2}\left(\mathrm{H}_{2} \mathrm{O}\right)\right]$ and $\left.\left[\mathrm{Sn}(\mathrm{HNSM}) \mathrm{Cl}_{2}\left(\mathrm{H}_{2} \mathrm{O}\right)_{2}\right]\right)$ are given in Table 2. The atomic absorption data for tin metal is also shown in Table 2. The general formula of complexes have been suggested as $\left[\mathrm{Sn}(\mathrm{L}) \mathrm{Cl}_{2} \cdot \mathrm{nH}_{2} \mathrm{O}\right]$ (where $\mathrm{L}$ is ligand, and $\mathrm{n}=1$ or 2 ,is the number of coordinated water).

Table 2. Elemental analysis and atomic absorption data of ligands and their corresponding complexes.

\begin{tabular}{|c|c|c|c|c|c|c|c|c|c|}
\hline \multirow[b]{2}{*}{ Compounds } & \multirow[b]{2}{*}{ Molecular formula } & \multicolumn{6}{|c|}{ Elemental analysis } & \multicolumn{2}{|c|}{$\begin{array}{l}\text { \% Metal } \\
\text { analysis }\end{array}$} \\
\hline & & $\begin{array}{l}\% \mathrm{C} \\
\mathrm{Cal} .\end{array}$ & $\begin{array}{c}\% \mathrm{C} \\
\text { Found }\end{array}$ & $\begin{array}{l}\% \mathrm{~N} \\
\mathrm{Cal} .\end{array}$ & $\begin{array}{c}\% \mathrm{~N} \\
\text { Found }\end{array}$ & \begin{tabular}{|l|}
$\% \mathrm{H}$ \\
$\mathrm{Cal}$. \\
\end{tabular} & \begin{tabular}{|c|}
$\% \mathrm{H}$ \\
Found \\
\end{tabular} & $\begin{array}{l}\mathrm{Sn} \% \\
\mathrm{Cal} . \\
\end{array}$ & $\begin{array}{l}\text { Sn \% } \\
\text { Found }\end{array}$ \\
\hline HNLH & $\mathrm{C}_{17} \mathrm{H}_{15} \mathrm{~N}_{3} \mathrm{O}_{3}$ & 66.01 & 66.15 & 13.58 & 13.24 & 2.89 & 2.73 & ----- & --- \\
\hline$\left[\mathrm{Sn}(\mathrm{HNLH}) \mathrm{Cl}_{2}\left(\mathrm{H}_{2} \mathrm{O}\right)\right]$ & $\mathrm{C}_{17} \mathrm{H}_{15} \mathrm{CI}_{2} \mathrm{~N}_{3} \mathrm{O}_{3} \mathrm{Sn}$ & 39.73 & 39.12 & 8.18 & 8.486 & 2.75 & 2.69 & 23.10 & 23.03 \\
\hline HNSM & $\mathrm{C}_{24} \mathrm{H}_{22} \mathrm{~N}_{4} \mathrm{O}_{3} \mathrm{~S}$ & 63.58 & 63.16 & 12.48 & 12.85 & 5.10 & 5.05 & ----- & ---- \\
\hline$\left[\mathrm{Sn}(\mathrm{HNSM}) \mathrm{Cl}_{2}\left(\mathrm{H}_{2} \mathrm{O}\right)_{2}\right]$ & $\mathrm{C}_{24} \mathrm{H}_{22} \mathrm{CI}_{2} \mathrm{~N}_{4} \mathrm{O}_{3} \mathrm{SSn}$ & 42.88 & 42.46 & 8.34 & 8.989 & 3.90 & 3.79 & 16.01 & 15.77 \\
\hline
\end{tabular}

\section{Infrared studies}

Relevant IR spectral bands of the ligands and their tin complexes along with their bands assignments are given in Table 3. In ligand $\mathrm{HNLH}$ and its complex [ $\mathrm{Sn}(\mathrm{HNLH}) \mathrm{Cl}_{2}\left(\mathrm{H}_{2} \mathrm{O}\right)$ ], the $v(\mathrm{C}=\mathrm{N})$ bands of ligand was appeared at $1626 \mathrm{~cm}^{-1}$ and this important band was shifted $(1620$ $\mathrm{cm}^{-1}$ ) in the spectra of the complex as indicated by the spectra of the tin complex. This shift is inferenced that tin ion is coordinated to the nitrogen atom of azomethine in the ligand. The $v\left(\mathrm{COO}^{-}\right)$bands at $1541 \mathrm{~cm}^{-1}$ and $1390 \mathrm{~cm}^{-1}$ for asymmetric and symmetric stretching in ligands are shifted to $1496 \mathrm{~cm}^{-1}$ and $1311 \mathrm{~cm}^{-1}$ in complexes. A new band at $3404 \mathrm{~cm}^{-1}$ is ascertained in the spectra of complex only and is assigned to $v\left(\mathrm{H}_{2} \mathrm{O}\right)[8,10,12]$.

In ligand HNSM and its complex [ $\left.\mathrm{Sn}(\mathrm{HNSM}) \mathrm{Cl}_{2}\left(\mathrm{H}_{2} \mathrm{O}\right)_{2}\right]$, the azomethine bands of the free ligand appeared at $1589 \mathrm{~cm}^{-1}$ and was shifted $\left(1564 \mathrm{~cm}^{-1}\right)$ as indicated by the spectra of the tin complex. This shift suggests that tin ion is coordinated to the nitrogen atom of azomethine in the ligand. The bands for $v\left(\mathrm{SO}_{2}\right)$ are observed at $1344 \mathrm{~cm}^{-1}$ and $1384 \mathrm{~cm}^{-1}$ in ligand and are assigned to $v\left(\mathrm{SO}_{2}\right)$ asymmetric and symmetric stretching. These bands have been shifted to $1138 \mathrm{~cm}^{-1}$ and $1149 \mathrm{~cm}^{-1}$ respectively in the case of complex. The band for $v(\mathrm{~S}-\mathrm{N})$ is observed at $974 \mathrm{~cm}^{-1}$ in ligand and is shifted to $1018 \mathrm{~cm}^{-1}$ in the spectra of tin complex. A new band is observed at $3383 \mathrm{~cm}^{-1}$ appears only in complex and is assigned to $\mathrm{v}\left(\mathrm{H}_{2} \mathrm{O}\right)[15,17,24]$. 
Table 3. FTIR data of ligands and their corresponding complexes.

\begin{tabular}{|c|c|c|c|c|c|c|c|c|}
\hline \multirow{2}{*}{ Compounds } & \multicolumn{9}{|c|}{ IR spectra $\left(\mathrm{cm}^{-1}\right)$} \\
\cline { 2 - 9 } & $\begin{array}{c}v \\
(\mathrm{C}=\mathrm{N})\end{array}$ & $\begin{array}{c}v\left(\mathrm{COO}^{-}\right) \\
(\text {asym, sym })\end{array}$ & $\begin{array}{c}v(\mathrm{CO}) \\
(\text { phenolic })\end{array}$ & $\begin{array}{c}v\left(\mathrm{SO}_{2}\right) \\
(\text { asym,sym })\end{array}$ & $v(\mathrm{~S}-\mathrm{N})$ & $v\left(\mathrm{H}_{2} \mathrm{O}\right)$ & $\begin{array}{c}v(\mathrm{C}-\mathrm{H}) \\
\text { Aromatic }\end{array}$ & $\begin{array}{c}v(\mathrm{C}-\mathrm{H}) \\
\text { Aliphatic }\end{array}$ \\
\hline $\mathrm{HNLH}$ & 1626 & $\begin{array}{c}1541, \\
1390\end{array}$ & 1355 & --- & ---- & ---- & 3145 & 2916 \\
\hline$\left[\mathrm{Sn}(\mathrm{HNLH}) \mathrm{Cl}_{2}\left(\mathrm{H}_{2} \mathrm{O}\right)_{2}\right]$ & 1620 & 1496, & 1334 & --- & ---- & 3404 & 3076 & 2889 \\
\hline $\mathrm{HNSM}$ & 1589 & ---- & ---- & 1344, & 974 & ---- & 3039 & 2792 \\
\hline$\left[\mathrm{Sn}(\mathrm{HNSM}) \mathrm{Cl}_{2}\left(\mathrm{H}_{2} \mathrm{O}_{2}\right]\right.$ & 1564 & ---- & ---- & 1138, & 1018 & 3383 & 3001 & ---- \\
\hline
\end{tabular}

\section{${ }^{I} H$ NMR studies}

The ${ }^{1} \mathrm{H}$ NMR spectra of the Schiff bases were determined in DMSO- $\mathrm{d}_{6}$. The ${ }^{1} \mathrm{H}$ NMR data of the two Schiff bases and their respective tin complexes are summarized in Table 4 . The signals for azomethine proton appear in the range of $8-10 \mathrm{ppm}$ which is characteristics of these protons. These peaks shift downfield as indicated in the ${ }^{1} \mathrm{H}$ NMR spectra of corresponding tin(II) complexes. Azomethine nitrogen contains lone pair of electrons. During coordinate bond formation, these lone pair of electrons are bonded to the tin(II) and this is the main cause of the de-shielding and downfield shift [5]. The signal for one proton in the range of 9-16 ppm for the ligands and their complexes corresponds to the $-\mathrm{OH}$ group attached to aromatic system. The phenolic hydroxyl proton appears in the range of 9-16 ppm. The signals shifted downfield in the spectra of the complexes indicating the coordination of oxygen of the - $\mathrm{OH}$ group with tin metal. In the case of complex [ $\mathrm{Sn}(\mathrm{HNSM}) \mathrm{Cl}_{2}\left(\mathrm{H}_{2} \mathrm{O}\right)_{2}$ ] the $-\mathrm{OH}$ signal disappeared indicating the deprotonation of oxygen atoms of the ligand on complexation [25]. The multiplets between 6.8$8.6 \mathrm{ppm}$ in the spectra of ligands and their respective tin(II) complexes are assigned to the naphthylidene group protons and other aromatic protons. These multiplets have downfield shift in the spectra of the corresponding tin(II) complexes. This suggests the increase in conjugation upon the formation of tin complexes with Schiff base ligands [5]. Aliphatic protons in the case of HNLH have been indicated in the range of 4.15-4.75 ppm and are assigned to $\mathrm{CH}_{2}$ - group. These protons have been shifted in the tin complex and appeared at 3.09-3.27 ppm. Heterocyclic protons in HNSM and its tin complex appeared in the range of 8.05-8.08 ppm and 8.12-8.2 ppm, respectively. Ligand $\mathrm{HNSM}$ and its complex $\left[\mathrm{Sn}(\mathrm{HNSM}) \mathrm{Cl}_{2}\left(\mathrm{H}_{2} \mathrm{O}\right)_{2}\right.$ ] exhibited $\mathrm{SO}_{2} \mathrm{NH}-$ peak at 3.36 and $3.82 \mathrm{ppm}$, respectively. In all the complexes new peak appeared in the region of 3.0$3.4 \mathrm{ppm}$ were assigned for coordinated water [18].

Table $4 .{ }^{1} \mathrm{H}$ NMR spectral data $(\delta$, ppm) of ligands and their corresponding complexes.

\begin{tabular}{|c|c|c|c|c|}
\hline Compounds & $-\mathrm{HC}=\mathrm{N}$ & $-\mathrm{OH}$ & Aromatic hydrogens & $\mathrm{SO}_{2}-\mathrm{NH}$ \\
\hline $\mathrm{HNLH}$ & 9.64 & 10.80 & $7.0-8.6$ & ------ \\
\hline$\left[\mathrm{Sn}(\mathrm{HNLH}) \mathrm{Cl}_{2}\left(\mathrm{H}_{2} \mathrm{O}\right)\right]$ & 8.85 & ---- & $6.68-7.88$ & ----- \\
\hline $\mathrm{HNSM}$ & 8.44 & 10.85 & $7.30-7.92$ & 3.33 \\
\hline$\left[\mathrm{Sn}(\mathrm{HNSM}) \mathrm{Cl}_{2}\left(\mathrm{H}_{2} \mathrm{O}\right)_{2}\right]$ & 8.58 & ----- & $7.01-7.85$ & 3.82 \\
\hline
\end{tabular}

${ }^{13}$ C NMR studies

${ }^{13} \mathrm{C}$ NMR Spectra of the compounds were recorded in DMSO- $\mathrm{d}_{6}$ and these spectra also support the authenticity of the proposed structures (Table 5). The signals observed in the range 156-171 ppm were due to azomethine carbons. These signals were shifted in the case of tin(II) complexes, indicating the coordination of azomethine nitrogen to the tin upon complexation 
[20]. The aliphatic carbons in the ligands HNLH and HNSM and their tin(II) complexes $\left[\mathrm{Sn}(\mathrm{HNLH}) \mathrm{Cl}_{2}\left(\mathrm{H}_{2} \mathrm{O}\right)\right]$ and $\left[\mathrm{Sn}(\mathrm{HNSM}) \mathrm{Cl}_{2}\left(\mathrm{H}_{2} \mathrm{O}\right)_{2}\right]$ were appeared in the range of 22-40 ppm. The aromatic carbon directly attached with azomethine carbon shows peak at 105-112 ppm. The aromatic carbon directly attached with azomethine nitrogen shows peak at 141-143.3 ppm. Signals in the range of $\delta 155-169 \mathrm{ppm}$ are assigned to the aromatic carbons attached to the $-\mathrm{OH}$ group in various ligands. The shifts were observed in these signals when the free Schiff base ligands were coordinated to the tin atom indicating the involvement of $-\mathrm{OH}$ group in complex formation. In the ${ }^{13} \mathrm{C}$ NMR spectra of the ligands, the signals observed in the range of $\delta 122-156$ ppm have been assigned to aromatic carbons attached to azomethine nitrogen. The shift in these signal are observed in the spectra of the respective complexes.

Table $5 .{ }^{13} \mathrm{C}-\mathrm{NMR}$ spectral data $(\delta$, ppm) of ligands and their corresponding complexes.

\begin{tabular}{|c|c|c|c|c|c|}
\hline Compounds & -HC=N & $\begin{array}{c}\text { Aromatic carbon } \\
\text { attached with } \\
\text {-OH group }\end{array}$ & $\begin{array}{c}\text { Aromatic carbon } \\
\text { attached with } \\
\text { azomethine Nitrogen }\end{array}$ & $\begin{array}{c}\text { Aliphatic } \\
\text { Carbon }\end{array}$ & $\begin{array}{c}\text { Aromatic carbon } \\
\text { attached with } \\
\text { azomethine Carbon }\end{array}$ \\
\hline $\mathrm{HNLH}$ & 171.81 & 158.84 & 122.00 & 40.33 & 105.95 \\
\hline$\left[\mathrm{Sn}(\mathrm{HNLH}) \mathrm{Cl}_{2}\left(\mathrm{H}_{2} \mathrm{O}\right)\right]$ & 165.19 & 169.70 & 133.06 & 25.77 & 108.34 \\
\hline $\mathrm{HNSM}$ & 171.46 & 167.38 & 156.64 & 22.77 & 108.79 \\
\hline$\left[\mathrm{Sn}(\mathrm{HNSM}) \mathrm{Cl}_{2}\left(\mathrm{H}_{2} \mathrm{O}\right)_{2}\right]$ & 156.94 & 155.31 & 130.56 & 23.04 & 112.07 \\
\hline
\end{tabular}

\section{Molar conductance}

The molar conductance of complexes $\left[\mathrm{Sn}(\mathrm{HNLH}) \mathrm{Cl}_{2}\left(\mathrm{H}_{2} \mathrm{O}\right)\right]$ and $\left[\mathrm{Sn}(\mathrm{HNSM}) \mathrm{Cl}_{2}\left(\mathrm{H}_{2} \mathrm{O}\right)_{2}\right]$ is reported in Table 6 . The molar conductance values have indicated that all the synthesized complexes were non-electrolytic in nature in DMF solvent. In non-electrolytic complexes the anion is bonded with metal and present within the coordination sphere while in electrolytic complexes the anion outside the coordination sphere. It has been supported by the low conductance data that the Schiff bases are coordinated to the tin atom in their deprotonated anionic forms and that the two chlorides ligands are also coordinated to the tin atom [20].

Table 6. Molar conductance studies of complexes.

\begin{tabular}{|c|c|c|c|c|}
\hline Complex & Solvent & $\begin{array}{c}\text { Weight } \\
\text { taken }(\mathrm{mg}) / \text { solvent } \\
\text { added }(40 \mathrm{~mL})\end{array}$ & $\begin{array}{c}\text { Molar } \\
\text { conductance } \\
\mathrm{Ohm}^{-1} \mathrm{~cm}^{2} \mathrm{~mol}^{-1}\end{array}$ & Inference \\
\hline$\left[\mathrm{Sn}(\mathrm{HNLH}) \mathrm{Cl}_{2}\left(\mathrm{H}_{2} \mathrm{O}\right)\right]$ & \multirow{2}{*}{ DMF } & 2.1 & 18 & Non-electrolyte \\
\hline$\left[\mathrm{Sn}(\mathrm{HNSM}) \mathrm{Cl}_{2}\left(\mathrm{H}_{2} \mathrm{O}\right)_{2}\right]$ & & 2.6 & 13.5 & Non-electrolyte \\
\hline
\end{tabular}

\section{Electronic absorption spectral studies}

The electronic absorption spectra of ligands and their Sn(II) complexes in DMF solution were carried out in the range of 200-1000 $\mathrm{nm}$ at room temperature as shown in Table 7 . There is a shift of the bands to longer $\lambda$ in spectra of all $\mathrm{Sn}(\mathrm{II})$ complexes which is a good evidence of complex formation. The bands observed at $270 \mathrm{~nm}$ and $280 \mathrm{~nm}$ in complexes and ligands both are attributed to intraligand $\pi-\pi^{*}$ transition of phenyl group. Band between $310 \mathrm{~nm}$ and at 400 $\mathrm{nm}$ in case of HNLH and HNSM ligands are due to $\mathrm{n}-\pi^{*}$ transition. In case of complexes the band at $430 \mathrm{~nm}$ (in the case of HNLH) and at $390 \mathrm{~nm}$ (in the case of HNSM) is due to charge transfer transitions. It has been reported that the metal is capable of forming dח-p ${ }^{*}$ bonds with ligands containing nitrogen as the donor atom. The tin ion has vacant $5 \mathrm{~d}$ orbital and consequently ligand-to-metal $(\mathrm{L} \rightarrow \mathrm{M})$ binding can take place by the acceptance of pair of electrons from ligand to the tin metal. No d-d transition is expected for tin complexes $[8,12,15$, $17,26,27]$. 
Table 7. Electronic spectral data of ligands and their corresponding complexes.

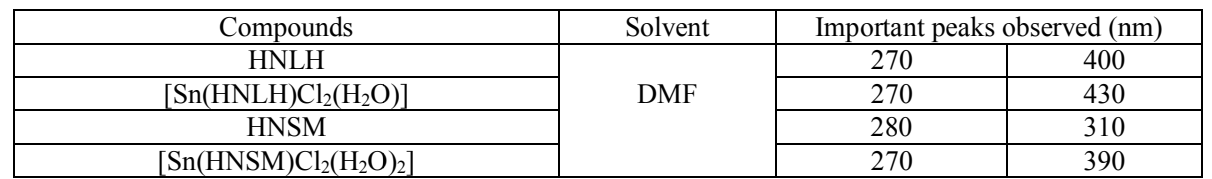
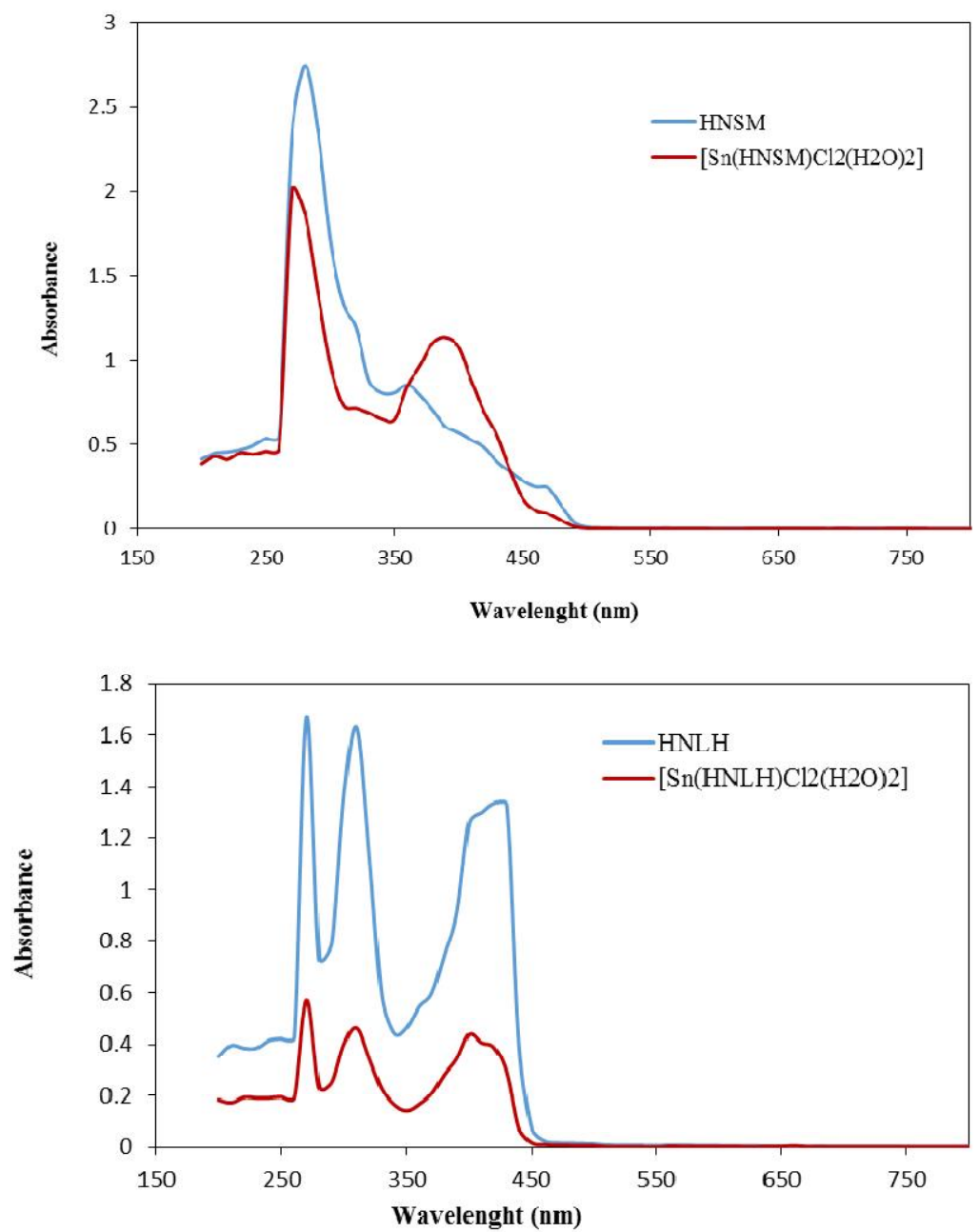

\section{Antibacterial activity}

In vitro antibacterial activity of the ligands and their corresponding tin complexes was tested against Gram-negative (Klebsiella pneumoniae and Escherichia coli) and Gram-positive (Staphylococcus aureus, Staphylococcus epidermidis and Bacillus subtilis) bacteria. The antibacterial activity results clearly showed that the synthesized ligands and their tin complexes 
were biological active as shown in Table 8 . The data obtained manifest that some of these compounds exhibited good activities against the tested organisms. Among the ligands and complexes, the highest activity were shown by HNLH against two bacterial species i.e. Klebsiella pneumonia and Staphylococcus aureus while its complex [ $\mathrm{Sn}(\mathrm{HNLH}) \mathrm{Cl}_{2}\left(\mathrm{H}_{2} \mathrm{O}\right)$ ] showed maximum activity against Escherichia coli among the tested bacteria. Ligand HNSM and its tin complex $\left[\mathrm{Sn}(\mathrm{HNSM}) \mathrm{Cl}_{2}\left(\mathrm{H}_{2} \mathrm{O}\right)_{2}\right.$ ] showed highest activity against Bacillus subtilis and Staphylococcus aureus, respectively.

Table 8. Antibacterial activities of ligands and their corresponding complexes.

\begin{tabular}{|c|c|c|c|c|c|}
\hline \multirow{2}{*}{ Compounds } & \multicolumn{5}{|c|}{ Average zone of inhibition (mm) } \\
\cline { 2 - 6 } & $\begin{array}{c}\text { Klebsiella } \\
\text { pneumoniae }\end{array}$ & $\begin{array}{c}\text { Escherichia } \\
\text { coli }\end{array}$ & $\begin{array}{c}\text { Staphylococcus } \\
\text { aureus }\end{array}$ & $\begin{array}{c}\text { Staphylococcus } \\
\text { epidermidis }\end{array}$ & $\begin{array}{c}\text { Bacillus } \\
\text { subtilis }\end{array}$ \\
\hline $\mathrm{HNLH}$ & 20 & 18 & 20 & 18 & 06 \\
\hline$\left[\mathrm{Sn}(\mathrm{HNLH}) \mathrm{Hl}_{2}\left(\mathrm{H}_{2} \mathrm{O}\right)\right]$ & 06 & 16 & 06 & 06 & 06 \\
\hline $\mathrm{HNSM}$ & 06 & 06 & 06 & 06 & 22 \\
\hline$\left[\mathrm{Sn}(\mathrm{HNSM}) \mathrm{Cl}_{2}\left(\mathrm{H}_{2} \mathrm{O}\right)_{2}\right]$ & 19 & 19 & 20 & 18 & 06 \\
\hline Standard & 24 & 25 & 24 & 26 & 28 \\
\hline
\end{tabular}

Anti-fungal activity

The synthesized ligands and their tin(II) complexes were also subjected to anti-fungal activity against three fungal strains (Aspergillus niger, Aspergillus flavus and Alternaria solani) as shown in Table 9. The antifungal activity results have shown that HNSM possessed highest activity against Aspergillus niger and Aspergillus flavus while Alternaria solani is mostly affected by $\left[\mathrm{Sn}(\mathrm{HNSM}) \mathrm{Cl}_{2}\left(\mathrm{H}_{2} \mathrm{O}\right)_{2}\right]$.

Table 9. Antifungal activities of ligands and their corresponding complexes.

\begin{tabular}{|c|c|c|c|}
\hline \multirow{2}{*}{ Compounds } & \multicolumn{3}{|c|}{ Mean value of percent growth inhibition } \\
\cline { 2 - 4 } & Aspergillus niger & Aspergillus flavus & Alternaria solani \\
\hline $\mathrm{HNLH}$ & 30 & 20 & 25 \\
\hline$\left[\mathrm{Sn}(\mathrm{HNLH}) \mathrm{Cl}_{2}\left(\mathrm{H}_{2} \mathrm{O}\right)_{2}\right]$ & 30 & 20 & 30 \\
\hline $\mathrm{HNSM}$ & 55 & 45 & 20 \\
\hline$\left[\mathrm{Sn}(\mathrm{HNSM}) \mathrm{Cl}_{2}\left(\mathrm{H}_{2} \mathrm{O}\right)_{2}\right]$ & 20 & 15 & 35 \\
\hline $\mathrm{DMSO}$ & 0 & 0 & 0 \\
\hline
\end{tabular}

Antioxidant activity-IC $C_{50}$ values

Free radicals, which are involved in the process of lipid peroxidation, are considered to play a major role in numerous chronic pathologies, such as cancer and cardiovascular diseases. A compound with radical reducing power may serve as a potential antioxidant [28]. The $\mathrm{IC}_{50}$ value, defined as the concentration of the sample leading to $50 \%$ reduction of the initial DPPH concentration, was calculated from the linear regression of plots of concentration of the tested compounds against the mean percentage of the antioxidant activity [29]. Antioxidants are free radicals scavengers that may prevent, protect, or reduce the extension of such damage. A number of chemical species including both synthetic and natural products may act as antioxidants [30]. The lower the $\mathrm{IC}_{50}$ value, the higher is antioxidant activity of the tested samples. $\mathrm{IC}_{50}$ values are given in Table 10 . The results showed that complexation with tin(II) ion have decreased the antioxidant activity of the ligands. The ligand HNSM and its complex $\left[\mathrm{Sn}(\mathrm{HNSM}) \mathrm{Cl}_{2}\left(\mathrm{H}_{2} \mathrm{O}\right)_{2}\right]$ have exhibited more antioxidant activity than ligand HNLH and its complex [Sn(HNLH) $\left.\mathrm{Cl}_{2}\left(\mathrm{H}_{2} \mathrm{O}\right)\right]$. 
Table 10. Antioxidant activities of ligands and their corresponding complexes.

\begin{tabular}{|c|c|c|}
\hline Compounds & IC $_{50}$ value $(\mathrm{ppm})$ & Inference \\
\hline $\mathrm{HNLH}$ & 1405.97 & antioxidant \\
\hline$\left[\mathrm{Sn}(\mathrm{HNLH}) \mathrm{Cl}_{2}\left(\mathrm{H}_{2} \mathrm{O}\right)\right]$ & 2031.04 & antioxidant \\
\hline $\mathrm{HNSM}$ & 118.87 & antioxidant \\
\hline$\left[\mathrm{Sn}(\mathrm{HNSM}) \mathrm{Cl}_{2}\left(\mathrm{H}_{2} \mathrm{O}\right)_{2}\right]$ & 361.16 & antioxidant \\
\hline
\end{tabular}

\section{CONCLUSION}

Various Schiff base ligands derived from the condensation of 2-hydroxy-1-naphthaldehyde with L-histidine and sulfamethazine have been successfully synthesized. These ligands were complexed with tin using tin(II) chloride. Coordination of phenolic oxygen (-OH) and azomethine nitrogen $(-\mathrm{C}=\mathrm{N}-)$ with tin(II) have been indicated by various studies hence it has been liable for imparting the stability to the complexes. The antimicrobial activities of the ligands and complexes have exhibited significant activities. Our present study has shown that between gram negative species Klebsiella pneumoniae $(20 \mathrm{~mm})$ for HNLH while among gram positive bacterial species Bacillus subtilis $(22 \mathrm{~mm})$ for HNSM have almost near to the standard drug used value. The highest antifungal activity was calculated against Aspergillus niger (55\%) and Aspergillus flavus (45\%) by HNSM. Complex [ $\mathrm{Sn}(\mathrm{HNSM}) \mathrm{Cl}_{2}\left(\mathrm{H}_{2} \mathrm{O}\right)_{2}$ ] exhibited highest activity against Alternaria solani $(35 \%)$. The antioxidant activities of ligand along with its complexes have shown a substantial increase in the activity. Maximum antioxidant activity was observed by HNSM (119 ppm) The results obtained herein have indicated that the synthesized ligands and their complexes have exhibited effective biological and antioxidant activities and have been used as a pharmaceutical agent.

\section{ACKNOWLEDGEMENT}

We are grateful to the Institute of Chemical Sciences University of Peshawar and PCSIR Labs Peshawar for providing research facilities.

\section{REFERENCES}

1. Yılmaz, F.; Karaali, N.; Şaşmaz, S. Microwave-assisted synthesis of some nitrobenzimidazoles and their salicyl and isatin Schiff bases. Bull. Chem. Soc. Ethiop. 2017, 31, 351-359.

2. Esmaielzadeh S.; Zare, Z.; Azimian, L. Synthesis, physical characterization, antibacterial activity and thermodynamic studies of five coordinate cobalt(III) Schiff base complexes. Bull. Chem. Soc. Ethiop. 2016, 30, 209-220.

3. El-Shahawi, M. Spectrophotometric determination of nickel(II) with some Schiff base ligands. Anal. Sci. 1991, 7, 443-446.

4. Neelakantan, M.A.; Rusalraj, F.; Dharmaraja, J.; Johnsonraja, S.; Jeyakumar, T.; Sankaranarayana, P.M. Spectral characterization, cyclic voltammetry, morphology, biological activities and DNA cleaving studies of amino acid Schiff base metal(II) complexes. Spectrochim. Acta. Part A: Mol. Biomol. Spectrosc. 2008, 71, 1599-1609.

5. Khedr, M.A.; Jadon, S.; Kumar, V. Synthesis, spectral analysis, and molecular modeling of bioactive Sn(II)-complexes with oxadiazole Schiff bases. J. Coord. Chem. 2011, 64, 13511359.

6. Ramírez-Jiménez, A.; Gómez, E.; Hernández, S. Penta- and heptacoordinated tin(IV) compounds derived from pyridine Schiff bases and 2-pyridine carboxylate: Synthesis and structural characterization. J. Organomet. Chem. 2009, 694, 2965-2975. 
7. Sharma, K.; Agarwal, S.; Gupta, S. Antifungal, antibacterial and antifertility activities of biologically active macrocyclic complexes of tin(II). Int. J. Chem. Tech. Res. 2013, 5, 456463.

8. Singh, L.H.; Singh, B.J. Synthesis and characterization of new lead(II) and organotin(IV) complexes of Schiff bases derived from histidine and methionine. Int. J. Inorg. Chem. 2012, 2012, 1-7.

9. Sadeek, A.S.; El-Attar, S.M.; Abd El-Hamid, M.S. Synthesis, characterization and antibacterial activity of some new transition metal complexes with ciprofloxacin-imine. Bull. Chem. Soc. Ethiop. 2015, 29, 259-274.

10. Abdel-Rahman, H.L.; El-Khatib, M.R.; Nassr, A.E.L.; Abu-Dief, M.A.; Lashin, E.F. Design, characterization, teratogenicity testing, antibacterial, antifungal and DNA interaction of few high spin Fe(II) Schiff base amino acid complexes. Spectrochim. Acta. Part A: Mol. Biomol. Spectrosc. 2013, 111, 266-276.

11. Garza-Ortiz, A.; Camacho-Camacho, C.; Sainz-Espuñes, T.; Irma Rojas-Oviedo, I.; Gutiérrez-Lucas, R.L.; Carrillo, G.A.; Ramirez, V.A.M. Novel organotin(IV) Schiff base complexes with histidine derivatives: Synthesis, characterization, and biological activity. Bioinorg. Chem. applic. 2013, 2013, 1-12.

12. Casella, L.; Gullotti, M. Coordination modes of histidine: Circular dichroism study of copper(II) complexes of the Schiff bases derived from (1R)-3-(hydroxymethylene) camphor and histidine derivatives. Inorg. Chem. 1981, 20, 1306-1308.

13. Mansour, M.A.; Ghani, A.T.N. Hydrogen-bond effect, spectroscopic and molecular structure investigation of sulfamethazine Schiff-base: Experimental and quantum chemical calculations. J. Mol. Struct. 2013, 1040, 226-237.

14. Krátký, M.; Vinsová, J.; Volková, M.; Buchta, V.; Trejtnar, F.; Stolaríková, J. Antimicrobial activity of sulfonamides containing 5-chloro-2-hydroxybenzaldehyde and 5-chloro-2hydroxybenzoic acid scaffold. Eur. J. Med. Chem. 2012, 50, 433-440.

15. Chohan, H.Z.; Shad, A.H.; Youssoufi, H.M.; Hadda, B.T. Some new biologically active metal-based sulfonamide. Eur. J. Med. Chem. 2010, 45, 2893-2901.

16. Boyd, E.A. Sulfonylurea receptors, ion channels, and fruit flies. Diabetes 1988, 37, 847-850.

17. Chohan, H.Z.; Supuran, T.C. Structure and biological properties of first row d-transition metal complexes with N-substituted sulfonamides. J. Enzym. Inhib. Med. Chem. 2008, 23, 240-251.

18. Singh, K.B.; Prakash, A.; Rajour, K.H.; Bhojak, N.; Adhikari, D. Spectroscopic characterization and biological activity of $\mathrm{Zn}(\mathrm{II}), \mathrm{Cd}(\mathrm{II}), \mathrm{Sn}(\mathrm{II})$ and $\mathrm{Pb}$ (II) complexes with Schiff base derived from pyrrole-2-carboxaldehyde and 2-amino phenol. Spectrochim. Acta Part A: Mol. Biomol. Spectrosc. 2010, 76, 376-383.

19. Neelofar; Ali, N.; Ahmad, S.; Abd El-Salam, M.N.; Ullah, R.; Nawaz, R.; Ahmad, S. Synthesis and evaluation of antioxidant and antimicrobial activities of Schiff base tin(II) complexes. Trop. J. Pharm. Res. 2016, 15, 2693-2700.

20. Chohan, H.Z.; Sumrra, H.S.; Youssoufi, H.M.; Hadda, B.T. Metal based biologically active compounds: Design, synthesis, and antibacterial/antifungal/cytotoxic properties of triazolederived Schiff bases and their oxovanadium(IV) complexes. Eur. J. Med. Chem. 2010, 45, 2739-2747.

21. Khan, H.; Jan, A.S.; Javed, M.; Shaheen, R.; Khan, Z.; Ahmad, A.; Safi, Z.S.; Imran, M. Nutritional composition, antioxidant and antimicrobial activities of selected wild edible plants. J. Food. Biochem. 2016, 40, 61-70.

22. Sirajuddin, M..; Ali, S.; Haider, A.; Shah, A.N.; Shah, A.; Khan, R.M. Synthesis, characterization, biological screenings and interaction with calf thymus DNA as well as electrochemical studies of adducts formed by azomethine [2-((3,5-dimethylphenylimino)methyl)phenol] and organotin(IV) chlorides. Polyhedron 2012, 40, 19-31. 
23. Khalaf, A.N.; Shakya, K.A.; Al-Othman, A.; El-Agbar, Z.; Farah, H. Antioxidant activity of some common plants. Turk. J.Biol. 2008, 32, 51-55.

24. Tailor, M.S.; Patel, H.U. Synthesis, spectroscopic characterization, antimicrobial activity and crystal structure of silver and copper complexes of sulfamethazine. J. Coord. Chem. 2015, 68, 2192-2207.

25. Aman, R.; Matela, G. Tin(IV) Complexes of Schiff base derived from amino acid: Synthesis and characteristic spectral studies. J. Chem. 2013, 2013, 1-4.

26. Singh, R.V.; Chaudhary, P.; Chauhan, S.; Swami, M. Microwave-assisted synthesis, characterization and biological screening of nitrogen-sulphur and nitrogen-oxygen donor ligands and their organotin(IV) complexes. Spectrochim. Acta. Part A: Mol. Biomol. Spectrosc. 2009, 72, 260-268.

27. Ali, A.M.; Mirza, H.A.; Hamid, A.S.H.M.; Bernhardt, V.P. Diphenyltin(IV) complexes of the 2-quinolinecarboxaldehyde Schiff bases of S-methyl- and S-benzyldithiocarbazate (Hqaldsme and Hqaldsbz): X-ray crystal structures of Hqaldsme and two conformers of its diphenyltin(IV) complex. Polyhedron 2005, 24, 383-390.

28. Imran, M.; Khan, H.; Shah, M.; Khan, R.; Khan, F. Chemical composition and antioxidant activity of certain Morus species. J. Zhejiang Univ.-Sci. B (Biomed. Biotechnol.) 2010, 11, 973-980.

29. Saritha, V.; Anilakumar, R.K.; Khanum, F. Antioxidant and antibacterial activity of Aloe vera gel extracts. Int. J. Pharm. Bio. Arch. 2010, 1, 376-384.

30. Khan, H.; Amin, H.; Ullah, A.; Saba, S.; Rafique, J.; Khan, K.; Ahmad, N.; Badshah, L.S. Antioxidant and antiplasmodial activities of bergenin and 11-O-galloylbergenin isolated from Mallotus philippensis. Oxid. Med. Cell Longev. 2016, 2016, 1-6. 